\section{Badawi $^{1}$ \\ Wiwi Hartati \\ Istyakara Muslichah}

\title{
THE EFFECT OF INFORMATIONAL AND INTERPERSONAL JUSTICE TOWARDS SATISFACTION WITH RECOVERY SERVICE THROUGH THE ROLE OF CUSTOMER EMOTION MEDIATION: A STUDY ON POST-MERGER RURAL CREDIT BANKS (BPR) IN INDONESIA
}

\begin{abstract}
The research objective is to explore the role of moving mediation on the influence of informational and interpersonal justice on satisfaction with service recovery, as well as broadening the impact of informational and interpersonal justice on satisfaction with service recovery at the Rural Bank (BPR) after merger. The data is collected through surveys of customers who experienced failure of bank credit services by rural banks (BPR) in the last two years which amounted to 127 respondents in Yogyakarta, Indonesia. The data analysis techniques used in this research are Structural Equation Modeling (SEM). The results of this study found that emotions (positive and negative emotions) mediate the influence of informational and interpersonal justice on satisfaction with service recovery. The results of this study confirm that informational and interpersonal justice can increase comfort with a revival of services at $B P R$ after merger. The results of this study provide a theoretical contribution to the development of models for service failures in the Banking Service Industry, especially in the Rural Banks $(B P R)$ after the merger in Indonesia. Also, the findings of this study are also useful for the Banking Services Industry as a strategy model to implement Financial Services Financial Authority regulations on Consumer protection.).
\end{abstract}

Keywords: Informational and Interpersonal Justice, Emotion and Satisfaction with Recovery Service

\section{Introduction}

The issue of the expectation discounting model is an issue that becomes much concern among academicians and practitioners in marketing and consumer behavior literature (Oliver 1997). The result of the expectation discounting model is the first service interaction as the basis of evaluation carried out by customers in the second interaction. Both interactions create an overall service experience. This result becomes the idea of conventional marketing that is marginalized into a dynamic process from the process of service marketing toward value evaluation of the overall experience in service (Ballantyne and Varey, 2008). Satisfaction and dissatisfaction toward a product or service will have an

\footnotetext{
${ }^{1}$ Corresponding author: Badawi

Email: badawi@umc.ac.id
} 
impact on behavioral patterns.

Informational justice becomes an important thing for a company in service recovery process. Informational justice provides information on every occurrence of negative reactions to service performance (Greenberg, 1990; Greenberg 1994). Several studies that examined informational justice such as the study from Ambrose et al. (2007) have used four justice, namely; distributive justice, procedural justice, interactional justice, and informational of the organization's response toward individual attitudes. Namkung (2008) tested the application of service evaluation concept on the issue of justice model (distributive, procedural, interactional, and informational justice) on the internal and external service failures. Some research result show that informational justice can increase the satisfaction with service recovery (Badawi, 2012), Skarlick et al. (2008) in his findings stated that informational justice mediates the effect between justice toward integrated interaction. Colquitt (2001), Badawi, et al, (2017) stated that informational justice has an effect on satisfaction with service recovery.

The study of the service failure shows that the role of interactional justice can explain the interpersonal if negative results occur in the service failure process. The study from Río-Lanza et al.(2009), stated that three justice; distributive, procedural, and interactional justice have an effect on satisfaction. The study from Badawi (2012) found that interactional justice can increase the satisfaction with complaint handling in services. Badawi, et al. (2017) stated that informational justice has a significant effect on the satisfaction with service recovery in banking services. However, some researchers, such as Thomson and Vivein (2001), found that interactional justice has no effect on satisfaction, but it affects repotronage intention.

Related to the role of customer emotion, some researchers develop their studies by involving the role of emotion the research of service and complaint behavior that centered on consumer behavior experience, such as Badawi (2012) in complaint behavior in the Service Industry, Wells and Lo Sciuto (1966) in purchase behavior, and Lee et al. (2007) in marketing. Some research findings indicate that customer emotions play a role in mediating the effect of distributive, procedural, interactional, and informational justice toward the satisfaction of complaint handling (Badawi, 2012). The result of the study from Tronvoll (2007), found that negative emotion has $97 \%$ cases when experiencing consumer failure experience, and emotions make a major contribution to the knowledge of the effect of emotions on attitudes, satisfaction, characteristics and tasks, and commitment (Fisher, 2000; Saavedra and Kwan, 2000) Smith and Bolton (2002) in their finding stated that strong emotional reaction can accelerate the service recovery process and become the basis for stopping or continuing consumer relations with the company. The study from Price et al. (1995) found that the failure of service transactions would lead to negative emotional responses. Dube' and Menon (1998), also highlighted that the important role of socialization in the formation of consumer interpersonal with service providers involve emotions. Thus, the feeling of satisfaction with services is expected to be broadly influenced by consistent levels of justice and individual behavior patterns (Solomon et al., 1985).

This research intends to fill the gap of the previous research by examining the effect of informational and interactional justice toward satisfaction with the service recovery. This research also wants to examine the role of customer emotion in informational and interactional justice toward the satisfaction with service recovery in the Rural Bank (BPR) sector after the merger in Indonesia. 


\section{Intermational Quality Conference}

\section{Literature review}

\subsection{Informational Justice, Customer Emotion, and Satisfaction with Service Recovery}

In business organization, the application of justice can be applied to manager, employee, and stakeholder of the organizations who view justice as a value that can unite and provide basic principles that are binding on all parties who have problems in creating stable social structure. Informational justice explains and ratifies the specified procedure. The procedure explanation provides information that is needed to evaluate the structural aspects of service recovery process (Colquitt et al., 2001), but the explanation is consider fair if there is good communication (BIES et al., 1988), logically relevant information (Shapiro and Buttner, 1988), and correctly determined in the absence of power factors (Folger et al., 1983)

Some researches indicate that an explanation of procedure in determining information affects perception of justice (Tyler and BIES, 1990). The research result from Badawi (2012) found that perceived informational justice can reduce customer emotions. Smith and Bolton (2002) in their findings stated that strong emotional reaction can accelerate the process of service recovery and become the basis to stop or continue consumer relationship with the company.

H1 : Perceived informational justice can reduce consumer emotion in the process of service recovery.

$\mathrm{H} 2$ : Perceived informational justice can accelerate the satisfaction with service recovery.

\subsection{Interactional Justice, Customer Emotion, and Satisfaction with Service Recovery}

One of the successes in handling customer complaints can be reached by building interpersonal interaction between company and customer in the process of service recovery. BIES and Moag (1986) introduced the construct of interactional justice to capture the quality of interpersonal relationship in the process of decision making as well as distributive and procedural justice. This construct gets empirical support for the effect of interpersonal relationship on attitudes and behavior (Brockner \& Greenberg, 1990; Greenberg, 1990). Interactional justice illustrates how people can be treated fair in the process of service recovery, such as the attitude of employees who are polite, empathetic, making effort to handle complaints, and also the willingness of the company to explain the complaint process. Interactional justice is related to the aspects of communication process between the sources and recipients of justice, such as politeness, honesty, and respect (BIES \& Moag, 1986; Tyler \& BIES, 1990). It is because interactional justice is determined by interpersonal behavior of the management representative. Interactional justice is also considered to be related to cognitive, affective, and behavioral reactions on management representative, which is direct supervisor as sources of justice (Cropanzano \& Prehar, 1999; Masterson, et al, 2000). Several empirical studies examine the relationship between interactional justice and emotion (Chebat and Slusarczyk, 2005; Schoefer and Ennew, 2005). Clemmer and Schneider (1996) in their research found that interactional justice has an effect on emotion. This finding shows that the involvement of employee interaction can encourage the satisfaction of complaint handling.

H3 : Perceived interactional justice can reduce customer emotion in the process of service recovery.

$\mathrm{H} 4$ : Perceived interactional justice can accelerate the satisfaction with service recovery 


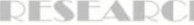

\subsection{Customer Emotion and Satisfaction with Service Recovery}

Emotion in complaint behavior is the main element in understanding purchase experience and consumer behavior (Oliver, 1997; Richins, 1997). Emotion is one of the keys of service recovery performance, which is satisfaction that is preceded by cognitive aspect. It is also added that the strength of customer emotional reaction is used as a basis to stop or continue consumer relationship with the company (Smith and Bolton, 2002). It means that if the resolution of a customer complaint is resolved properly, then positive and happy emotional reaction will occur, and there will be a satisfaction with the result of complaint handling. On the contrary, negative emotions will occur when the complaint handling performance is not in accordance with what is expected.

The research result from Chebat and Slusarczyk (2005) stated that there is the effect of justice toward loyalty behavior and is directly mediated by emotions. Río-Lanza et al. (2002) showed in his research result that negative emotion has a negative effect on the satisfaction with the complaint handling process. It is also added that distributive, procedural, and interactional justice affects toward the satisfaction of complaint handling. This research result implies that customers expect companies to process complaints, solve problems, and increase satisfaction in of complaint handling. This finding also suggests that the involvement of employee interaction in delivering services is an important value in the complaint handling process (Oliver, 1997; Richins, 1997).

Fisher (2000) stated that there is a relationship between recovery, justice, and emotion effect as a predictor toward satisfaction with complaint handling. The findings from SooCheong (Shwan) Namkung and Jang (2007) stated that service and atmosphere function can stimulate the positive energy of emotion in product attributes, such as product quality. It also stated that response in negative emotion can mediates the relationship between service atmosphere and behavioral performance in the future.

H4 : Customer emotion can increase the satisfaction with service recovery.

\section{Research Method}

This research is a causality research that aims to analyze the presence or absence of the relationship between variables. The analysis unit is individuals or customers who experienced service failures in the credit product in Rural Bank (BPR) after merger in West Java and Yogyakarta, Indonesia, which is 127 respondents. The sampling technique in this research is using accidental sampling. The distribution of the questionnaire is done by: 1) go directly to Rural Bank (BPR) in each region; and 2) ask customers directly related to service failure. The data collection method used in this research is sample survey research design by collecting on one sample and one time point (Malhotra, 2004). The questionnaire is distributed to the customer of Rural Bank (BPR) in West Java, which is Kuningan District (in Majalengka, Cirebon Regency, Cirebon City), Indramayu, and Yogyakarta. The measurement of the variable in this research adopted from: (1) Informational Justice, consists of three indicators adopted from Colquitt et al., (2001), Badawi, et, al (2017); (2) Interactional Justice consists of four indicators adopted from Schoefer and Ennew, (2005), Badawi, (2012); (3) Customer Emotion, consists of four indicators adopted Badawi, (2012); (4) Satisfaction with service recovery, consists of four indicators adopted from Namkung and Jang (2007), Badawi, et al (2017). The scale technique that is used is Likert Scale ranging from 1 (very strongly disagree) to 5 (very strongly agree). The statistic technique is using Structural Equation Modeling (SEM) with AMOS 22. The validity and reliability test that is found is valid and 


\section{Interinational Cuality Conference 1 .}

reliable.

\section{Data Analysis and Discussion}

The profile of the respondents are mostly men (72.36) and women (27.64\%). The age of the respondents are 20-35 years old $(32.58 \%), 35$ - 45 years old $(44,7 \%)$, and > 45 years old $(31.7 \%)$. The education of the respondents are Elementary School (18\%), Junior High School (38\%), and Senior High
School (43\%), and Higher Education (9,7\%). The number of complaints are 1-2 times (16.2\%), 3- 4 times (47.1\%), and $>5$ times $(49.5 \%)$.

Foigure 1 is the result of path analysis with AMOS 22 software to test the causal relationship between construct that is used in the hypothesized path model. The test of the structural model generally results in fit indices model.

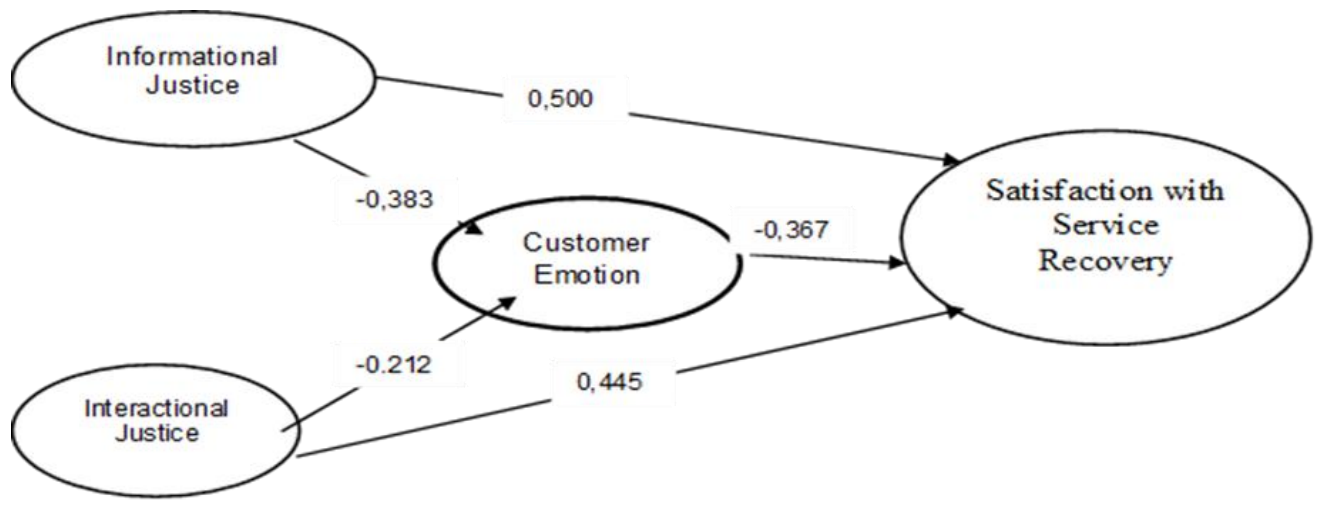

Figure 1. The Results of Informational and Interactional Justice, Customer Emotion, and Satisfaction with Service Recovery Equation Model

Table 1. The Effect of Dependent and Independent Variable in Structural Model

\begin{tabular}{|l|l|l|c|l|c|l|}
\hline & \multicolumn{2}{|c|}{ Relationships Between Variables } & Standardized & Unstandardized & P_value & Notes \\
\hline H1 & $\begin{array}{l}\text { Informasional } \\
\text { Justice }\end{array}$ & Customer Emotion & -0.383 & -3.749 & 0.000 & Significant \\
\hline H2 & $\begin{array}{l}\text { Interactional } \\
\text { Justice }\end{array}$ & Customer Emotion & -0.212 & -2.298 & 0.022 & Significant \\
\hline H3 & $\begin{array}{l}\text { Customer } \\
\text { Emotion }\end{array}$ & $\begin{array}{l}\text { Satisfaction with } \\
\text { Service Recovery }\end{array}$ & -0.367 & -3.789 & 0.000 & $\begin{array}{l}\text { Non- } \\
\text { Significant }\end{array}$ \\
\hline H4 & $\begin{array}{l}\text { Informational } \\
\text { Justice }\end{array}$ & $\begin{array}{l}\text { Satisfaction with } \\
\text { Service Recovery }\end{array}$ & 0.500 & 5.954 & 0.000 & Significant \\
\hline H5 & $\begin{array}{l}\text { Interactional } \\
\text { Justice }\end{array}$ & $\begin{array}{l}\text { Satisfaction with } \\
\text { Service Recovery }\end{array}$ & 0.445 & 5.438 & 0.000 & Significant \\
\hline
\end{tabular}

In table 1, there are five hypothesis proposed. H1: Perceived informational justice can reduce Customer Emotion, with the value of $\beta-0.383$ or with P-value $0,000<$ 0,05. H2: Perceived interactional justice can reduce Customer Emotion with the value of $\beta-0.212$ or $\mathrm{P}$-value $0,022<0,05 \mathrm{H} 3$ : The decrease in Customer Emotion can increase the Satisfaction with Service Recovery with the value of $\beta-0.367$ or $\mathrm{P}$-value $0,000<$ 0,05. H4: Informational Justice can increase the Satisfaction with Service Recovery with the value of $\beta 0.500$ or $P$-value $0,00<0,05$. H5: Interactional Justice can increase the 
Satisfaction with Service Recovery with the

value of $\beta 0.445$ or $P$-value $0,000<0,05$.

Table 2. Indirect Effect and Total Effect of Informational and Interactional Justice toward Satisfaction with Service Recovery through Customer Emotion

\begin{tabular}{|l|l|l|l|l|l|}
\hline $\begin{array}{l}\text { Independent } \\
\text { Variables }\end{array}$ & $\begin{array}{l}\text { Mediation } \\
\text { Variable }\end{array}$ & Dependent Variables & $\begin{array}{l}\text { Indirect } \\
\text { Effect }\end{array}$ & $\begin{array}{l}\text { Total } \\
\text { effect }\end{array}$ & $\begin{array}{l}\text { P- } \\
\text { Value }\end{array}$ \\
\hline $\begin{array}{l}\text { Informational } \\
\text { Justice }\end{array}$ & $\begin{array}{l}\text { Customer } \\
\text { Emotion }\end{array}$ & $\begin{array}{l}\text { Satisfaction with Service } \\
\text { Recovery }\end{array}$ & -0.200 & -0.633 & 0.000 \\
\hline $\begin{array}{l}\text { Interactional } \\
\text { Justice }\end{array}$ & $\begin{array}{l}\text { Customer } \\
\text { Emotion }\end{array}$ & $\begin{array}{l}\text { Satisfaction with Service } \\
\text { Recovery }\end{array}$ & -0.185 & -0.506 & 0.000 \\
\hline
\end{tabular}

Table 2 shows that customer emotion mediates the effect of informational and interactional justice toward the satisfaction of service recovery with the total value of 0.633 or $\mathrm{P}$-value $0,000<0,05$ and interactional justice -0.506 or P-value 0,000 $<0,05$.

\section{Discussion And Conclusion}

\subsection{Discussion}

The result of the model described in Figure 1 and Table 1 show some research findings on the dynamics of service failure experiences reflected from the alignment between expectation and reality in the service recovery process. The main contribution of this study is the dynamics of service failure experience at Rural Bank (BPR) after merger which becomes major problems that must be responded quickly by companies with informational and interactional justice approaches to create positive emotions for bank customers. In general, this research yields findings which show that company in handling the complaint process can turn the negative emotion reactions into positive emotion by providing perceived informational and interactional justice in the process of service recovery and can increase the satisfaction with service recovery. This finding can explain the importance of justice (interactional and informational) in the company response toward the process of service recovery (customer complaint) in order to solve the problems faced by customers. Justice approach is also one of the good strategies to reduce customer emotions and have an impact on satisfaction with service recovery.

In particular, this finding is consistent with the research result from Lazarus (1991) which confirms that the emergence of negative emotions is the result of cognitive assessment of the state of situation. According to Lazarus (1991), cognitive assessment can form emotional responses. This finding also shows that the cognitive assessment theory in complaint experience is in accordance with the result of Nyer (1997) and Badawi (2012). Perceived informational and interactional justice in the process of service recovery is a reflection that represents the dimension of cognitive assessment that can explain the level of customer emotional elasticity in the process of service recovery.

The research result also found that informational and interactional justice perceived by customers can reduce the negative emotions of the customers such as anger, irritation, feelings of offense, and disappointment, or in other words, it can change from negative emotions to positive emotions, such as feeling happy and proud. On the contrary, the low level of perceived justice can increase negative emotion such as anger, disappointment, and et cetera. This finding is also consistent to the development of social psychological theory which emphasizes that emotion is one of the justice mediators that is perceived (Mikula et al., 1998; Greenberg, and Cohen, .1982). The finding of this research strengthens the 
research result from Badawi (2012) that informational justice perfect justice dimension as a tool to explain the required procedures to evaluate structural aspects of the process of service recovery, especially in the sector of banking service of Rural Bank in Indonesia.

In particular, this finding has a theory implication on informational and interactional justice, and it has a relatively similar importance in explaining the satisfaction with service recovery triggered by negative emotions to become positive emotions. In addition, the role of customer emotion can increase the effect of informational and interactional justice toward the satisfaction improvement of service recovery. For that, the company managerial must provide balanced information through the delivery of information, adequate information, and inform the results. These findings have several benefits that can help to manage by providing clear information in compensation offer on handling customer complaints in terms of (a) preventing an increase of customer dissatisfaction of the process of service recovery that is considered by customers that the bank is not serious in handling complaints, and (b) increasing customer trust in the promises of the Rural Bank (BPR) that provide service recovery procedures.

Future research can use different object such as manufacturing industry in business market, and also test the height and significance of justice. This approach enables it to explore justice and emotions deeper in order to find the satisfaction with service recovery.

\subsection{Conclusion}

Specifically, this research found that informational and interactional justice perceived by customers can be strengthened through providing adequate information, the way the company delivered the information, informing the proven results, becoming the strongest variable to reduce customer emotion, and increasing the satisfaction with complaint handling. The low level of emotion perceived by customers is able to explain and strengthen the effect of informational and interactional justice on satisfaction with service recovery.

\section{References:}

Ambrose M. L, Ronald L. Hess, Shankar Ganesan (2007). The relationship between justice and attitudes: An examination of justice eVects on event and system-related attitudes, Organizational Behavior and Human Decision Processes 103 21-36

Badawi, Tjahjono H.K., Muafi. (2017). The Role Of Corporate Reputation Moderation Of Banking Services, Olish Journal Of Management Studies, Vol.15 No.1

Badawi. (2012). Justice and Customer Emotion's Effect on Complaint Handling Satisfaction: A Survey on Complaint Attitude Handling. International Journal of Innovation, Management and Technology, Vol. 3, No. 5, pp. 573-579, 2012

Ballantyne, D., \& Varey, R. J. (2008). The service-dominant logic and the future of marketing. Journal of the Academy of Marketing Science, 36(1), 11-14

Bies, R. J., \& Moag, J. S. (1986). Interactional justice: Communication critera for fairness. Research on negotiation in organizations(Vol. 1, pp. 43-55). Greenwich, CT: JAI Press

Bies, R. J., Shapiro, D. L., \& Cummings, L. L. (1988).. Causal Accounts and Managing Organizational Conflict Is It Enough to Say It's Not My Fault? Communication Research, 15(4), 381-399.

Brockner, J. and J. Greenberg (1990), 'The Impact of Layoffs on Survivors: An Organisational 
QUA II II

MIIFSIFAIRQII

Justice Perspective.' In J. Carrol (ed.), Applied Social Psychological and Organisational Setting. Hillsdale, NJ: Erlbaum. pp. 45-75

Chebat, J.C. \& Slusarczyk, W.,(2005). How emotions mediate the effects of perceived justice on loyalty in service recovery situations: an empirical study. Journal of Business Research, 58(5), p.664-673.

Clemmer, E. C., \& Schneider, B. (1996). Fair service. in services marketing and management (pp. 109-126). Greenwich, CT: JAI Press.

Clemmer, E. C., \& Schneider, B. (1996). Fair Service. In T. A. Swartz, D. E. Bowen, \& S. W. Brown (Eds.), Advances in services marketing and management (Vol. 5, pp. 109-126). Greenwich, Connecticut: JAI Press Inc

Colquitt, J.A. (2001), On the dimensionality of organizational justice: a construct validation of a measure", Journal of Applied Psychology, Vol. 86 No. 3, pp. 386-400

Cropanzano, R. \& Prehar, C. A. (1999). Using social exchange theory to distinguish procedural and interactional justice. Paper presented at the annual meeting of the Society for Industrial and Organizational Psychology, Atlanta, GA.

Dube'-Rioux, L. and Menon, K. (1998). Why would certain types of in-process negative emotions increase post- purchase consumer satisfaction with services?", Advances in Services Marketing and Management, No. 7, JAI Press, Cincinnati, OH, pp. 131-58.

Fisher, C. (2000). Mood and emotions while working: Missing pieces of job satisfaction? Journal of Organizational Behavior, 21, 185-202

Folger, R., Rosenfield, D, \& Robinson, T. (1983). Relative deprivation and procedural justifications. Journal of Personality and Social Psychology, 45, 268-27

Greenberg, J. (1990),. Employee theft as a reaction to underpayment inequity: the hidden cost of pay cuts", Journal of Applied Psychology, Vol. 75 No. 5, pp. 561-568

Greenberg, J. (1993). The social side of fairness: Interpersonal and informational classes of organizational justice. Approaching fairness in human resource management (pp. 79-103). Associates, Hillsdale, NJ: Lawrence Erlbaum

Greenberg, J., \& Cohen, R. L. (1982). Equity and justice in social behavior. New York: Academic

Lazarus, R. S. (1991). Emotion and adaptation. New York: Oxford University Press

Lee, C., Yoon, Y. and Lee, S. (2007). Investigating the Relationships Among Perceived Value, Satisfaction, and Recommendations: The Case of the Korean DMZ. Tourism Management. 28(1): 204-214.

Malhotra, N.K. (2004). Marketing Research: An Applied Orientation. 4th Edition. New Jersey: Pearson Education Inc.

Masterson, S.S., Lewis, K., Goldman, B.M. and Taylor, M.S. (2000). Integrating Justice and Social Exchange: The Differing Effects of Fair Procedures and Treatment on Work Relationships. Academy of Management Journal, 43, 738-748.

Mikula, G., Scherer, K. R., \& Athenstaedt, U. (1998) The role of injustice in the elicitation of differential emotional reactions. Personality and Social Psychology Bulletin, 24, 769-783

Namkung, Y. \& Jang, S.(2008). Are highly satisfied restaurant customers really different? A quality perception perspective. International Journal of Contemporary Hospitality Management, 20(2):142-155.

Namkung, Y., \& Jang, S. (2007). Does food quality really matter in restaurants? Its impact on customer satisfaction and behavioral intentions. Journal of Hospitality and Tourism Research, 31, 387-410

Nyer, PU (1997), 'Modeling the Cognitive Antecedents of Post-Consumption Emotions', Journal of Consumer Satisfaction, Dissatisfaction and Complaining Behavior, vol. 10, pp. 
80-90.

Oliver, R. L.( 1997). Satisfaction. A behavioural perspective on the consumer. McGraw-Hill

Price, L. L., \& Arnould, E. J. (1999). Commercial friendships: Service provider-client relationships in context. Journal of Marketing, 63, 38-56

Richins Marsha L. 1997; Measuring emotions in the consumption experience. J Consum Res 24(2): $127-46$

Río-Lanza Ana Belén del Rodolfo Vázquez-Casielles Ana Ma Díaz-Martín, 2009, Satisfaction with service recovery: Perceived justice and emotional responses. Journal of Business Research 62, 775-781

Rio-Lanza, A.B., Vázquez-Casielles, R., Díaz-Martín, A.M., 2002. Satisfaction with Service Recovery: Perceived Justice and Emotional Responses" J Bus Res.

Saavedra, R., and Kwun, S. K. (2000). Affective states in job characteristics theory.Journal of Organizational Behavior,21, 131-146

Schoefer, K. and Ennew, C., (2005). The impact of perceived justice on consumers' emotional responses to service complaint experiences. Journal of Services Marketing, 19(5), p.261-270

Shapiro, D. L. - Buttner, E. H. (1988). Adequate Explanations: What Are They, and Do They Enhance Procedural Justice Under Severe Outcome Circumstances"? Paper Presented At the National Meeting of the Academy of Management, Anaheim, CA

Skarlicki. Daniel P. Laurie J. Barclay. Douglas Pugh, (2008), When explanations for layoffs are not enough: Employer's integrity as a moderator of the relationship between informational justice and retaliation. Journal of Occupational and Organizational Psychology 81, 123-146

Smith, A.K. and Bolton, R.N. (2002). The effects of customers, emotional responses to service failures on their recovery effort evaluations and satisfaction judgments", Journal of the Academy of Marketing Science, Vol. 30 No. 1, pp. 5-23.

Solomon, M. R., Surprenant, C., Czepiel, J. A. and Gutman, E. G. (1985). A role theory perspective on dyadic interactions: the service encounter, Journal of Marketing, 49, 1, 99111

Thomson S.H. Teo.and Vivein K.G.Lim (2001), The Effect Of Percieved Justice On Satisfaction and Behavioral Intention: The Case of Computer Purchase, International Journal Of Retail \& Distribution Management, Valume 29 Number 2 109-124

Tronvoll, B. (2007). Customer complaint behaviour from the perspective of the servicedominant logic of marketing", Managing Service Quality, Vol. 17 No. 6, pp. 601-20.

Tyler, T. R., \& Bies, R. J. (1990). Beyond formal procedures: The interpersonal context of procedural justice. In J. S. Carroll (Ed.), Applied social psychology in organizational settings (pp. 77-98). Hillsdale, NJ: Lawrence Erlbaum

Wells, William D. and Leonard Lo Sciuto . (1966). Direct Observation of Purchasing Behavior," Journal of Marketing Research, 3(August), 227-233

\section{Badawi}

Universitas Muhammadiyah

Cirebon

Indonesia

badawi@umc.ac.id

\section{Wiwi Hartati}

Universitas Muhammadiyah

Cirebon

Indonesia

wiwihartati@umc.ac.id

\section{Istyakara Muslichah}

Universitas Islam Indonesia

Indonesia

istyakara@uii.ac.i 


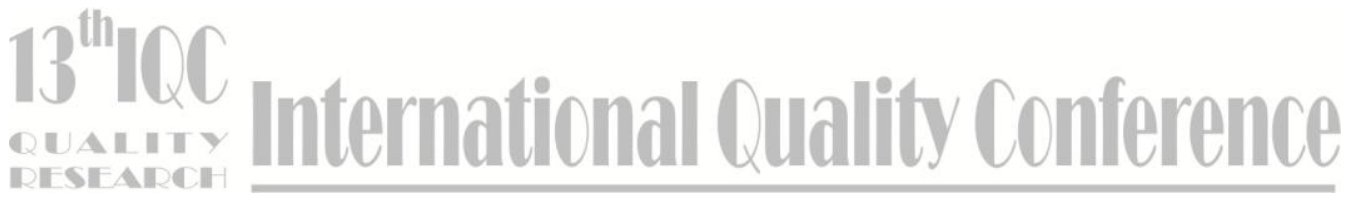

